\title{
"The Right of the People Shall Not Be Violated":The Evolution of Constitutional Rights in New Jersey
}

\author{
Robert F. Williams ${ }^{1}$
}

This is an expanded and footnoted version of a lecture delivered by Robert $F$. Williams at the New Jersey Historical Commission's 2009 Annual Conference, "New Jersey and the Bill of Rights," held on November $21^{\text {st }}$ in Trenton, New Jersey. The quote in the title comes from Article I, Paragraph 6 of the 1844 New Jersey Constitution.

The current picture concerning constitutional rights in New Jersey reflects a complex interrelationship of federal and state guaranteed rights. This twenty-first-century constitutional rights landscape has evolved over the more than two centuries since Independence. There were, in fact, important pre-Independence, colonial rights as well. ${ }^{2}$ Those matters, however, are beyond the scope of this lecture. I will begin at the point where New Jersey adopted its first state constitution.

\section{New Jersey's First State Constitution}

New Jersey adopted its first state constitution, interestingly, on July 2, 1776, two days before the Declaration of Independence. ${ }^{3}$ This constitution, which was drafted hurriedly, did not contain a separate declaration of rights as did many other early state constitutions. It did, however, contain several important rights embedded in the body of the constitution. The right to jury trial, voting rights (Blacks and women voted in New Jersey between 1790 and 1807), rights of accused criminals, an early statement of religious freedom, and a prohibition on discrimination against Protestants were included. ${ }^{4}$

Importantly, the jury trial right in New Jersey's 1776 constitution gave rise to a very important early example of constitutional litigation; a case that is now generally acknowledged to be the first example of judicial review (a court declaring a law unconstitutional) in the history of our country. ${ }^{5}$ In this 1780 case, the New Jersey court declared a statute unconstitutional because it provided for only a six-man jury (instead of twelve) in prosecutions for trading with the British.

New Jersey's 1776 constitution did not contain a process for its amendment. This proved to cause a number of problems, leading to this first constitution remaining in effect until 1844.

1 Robert F. Williams is a Distinguished Professor of Law at the Rutgers University School of Law, Camden.

2 Scott D. Gerber, A Distinct Judicial Power: The Origins of an Independent Judiciary, 1606-1787 (forthcoming).

3 Robert F. Williams, The New Jersey State Constitution: A Reference Guide 1 (Rev'd Ed. 1997).

4 id., at 2-3.

5 Austin Scott, Holmes v. Walton: The New Jersey Precedent, 4 Am. Hist. Rev. 456 (1889); Charles Erdman, Jr. The New Jersey Constitution of 1776 at 90-92 (1929); Scott D. Gerber, supra, note 1. 
New Jersey History 125:1

\section{The Federal Constitution and Bill of Rights}

New Jersey had ratified the proposed federal Constitution in December, 1787, with virtually no opposition. ${ }^{6}$ Anti-Federalists had opposed its adoption in other states using, among other criticisms, that it did not include a bill of rights. This argument concerning the necessity for a bill of rights arose from the examples of a number of the other states' early constitutions, which did contain such declarations or bills of rights. Obviously, that was not an argument that would be likely to surface in New Jersey because it was one of the few states where the constitution did not contain a separate bill of rights.

New Jersey then became the first state to ratify the ten amendments to the federal Constitution, presented as the Bill of Rights, in November, 1789. Once again, there was no discernable opposition. ${ }^{7}$ The federal Bill of Rights, of course, had been copied mainly from the rights guaranteed in state constitutions that had separate bills of rights, together with rights provisions suggested by the states during the process of ratifying the federal Constitution itself. ${ }^{8}$ Here again, of course, New Jersey's first constitution could not serve as a model because of the absence of a separate declaration of rights.

According to the basic political and legal understanding of that time, the federal Bill of Rights limited only the federal government. In other words, people in the states could not invoke the federal rights guarantees against the actions of their state or local governments. Therefore, in a state that did not have a separate declaration of rights, such as New Jersey, it would seem as though there were, literally, no constitutional rights! In fact, however, recent research has indicated that many state courts, including New Jersey's, did in fact apply the federal Bill of Rights in litigation where state and local actions were challenged in court. ${ }^{9}$ Further, as noted earlier, there were a few rights embedded in the body of the New Jersey Constitution of 1776 and these were enforced by the courts. ${ }^{10}$

\section{New Jersey's 1844 Constitution}

After many decades of agitation for a new state constitution in New Jersey, the legislature acted in 1844 without any specific constitutional authorization to call a constitutional convention and permit the people to vote for delegates. ${ }^{11}$ This constitutional convention led to the adoption of New Jersey's Constitution of 1844, which did contain a separate declaration of rights. This catalog of rights forms the basis of our state constitutional declaration of rights today.

\footnotetext{
${ }^{6}$ Eugene R. Sheridan, A Study In Paradox: New Jersey and the Bill of Rights, The Bill of Rights and the States: The Colonial and Revolutionary Origins of American Liberties 247-273 (Patrick T. Conley and John P. Kaminski, eds., 1992).

${ }^{7}$ Id.

${ }^{8}$ Bernard Schwartz, The Great Rights of Mankind: A History of the American Bill of Rights 53-54, 85-86, 90-91 (1977); Donald S. Lutz, The States and the Bill of Rights, 16 So. Ill. L.J. 251 (1992).

${ }^{9}$ Jason Mazzone, The Bill of Rights In The Early State Courts, 92 Minn. L. Rev. 1, 40-41, 55 (2007) (New Jersey cases).

${ }^{10}$ Erdman, supra note 4, at 4.

${ }^{11}$ Williams, supra note 2 , at 6.
} 
Interestingly, however, it did not guarantee the right to bear arms or provide protection against self incrimination. It did include an "unenumerated rights clause," often referred to as a "savings clause." This currently reads: "This enumeration of rights and privileges shall not be construed to impair or deny others retained by the people.",

After 1844, a very important year in the constitutional history of New Jersey, the state constitution's Declaration of Rights was available for people in New Jersey to rely upon directly in litigation. Still, according to the common understanding of the function of the federal Constitution, the federal Bill of Rights was not available directly to protect state citizens from their state and local governments; it was thought only to provide a shield against federal deprivation of rights.

\section{The Fourteenth Amendment to the United States Constitution}

In 1868, the states ratified the Fourteenth Amendment to the United States Constitution. This extremely important post-Civil War step accomplished a fundamental rearrangement of the relationship between the federal government and the states. Of particular importance was the Due Process Clause of the Fourteenth Amendment: "No State... shall... deprive any person of life, liberty, or property, without due process of law..." This clause provided a direct, textual guarantee of constitutional rights for people against their own states. This, it must be remembered, was not the original understanding of the federal Bill of Rights. Soon, questions began to arise as to what constituted "due process of law." Was it just up to the federal and state judges who enforced the United States Constitution to figure out on their own what was required? Against this possibility, the United States Supreme Court began to engage in a process of 'selective incorporation' of the federal Bill of Rights against the states. In other words, the United States Supreme Court began to fill in the definition of due process of law by relying on what was already in the federal Bill of Rights. After a long period of years, virtually all of the rights guaranteed in the federal Bill of Rights have now been deemed to apply to the states and to local government. The only exceptions to this date are the Seventh Amendment right to jury trial in civil courts, and the Second Amendment right to bear arms.

\section{Federal Bill of Rights Cases in New Jersey}

A number of famous cases in the United States Supreme Court under the federal Bill of Rights have come from New Jersey. They have ruled both for and against rights. One of the most important cases was the 1939 decision in Hague v. CIO ${ }^{13}$ In this decision, the United States Supreme Court struck down a ban imposed by the famous Mayor Frank Hague of Jersey City against union informational picketing as an arbitrary suppression of free speech in violation of the First Amendment.

In 1947, the United States Supreme Court ruled, in Everson v. Board of Education of Ewing

\footnotetext{
12 N.J. Const. art. I $§ 21$. See Williams supra note 2, at 48-49.

13307 U.S. 496 (1939); Benjamin Kaplan, The Great Civil Rights Case of Hague v. CIO: Notes of a Survivor, 25 Suffolk U.L. Rev. 913 (1991).
} 
Township, ${ }^{14}$ that providing school bus transportation to Catholic schools was not a violation of the First Amendment's clause barring government establishment of religion. ${ }^{15}$ In 1976, the Supreme Court upheld a ban on anti-war picketing on a military base in New Jersey by the famous baby doctor, Benjamin Spock. ${ }^{16}$ In 1981, the Court made clear that the First Amendment's freedom of expression guarantee permitted topless dancing in Mount Ephraim. ${ }^{17}$ Then, in 1984, it ruled that it was not an unconstitutional search and seizure under the Fourth Amendment for school officials to search a student's pocketbook without "probable cause."18

In 2000, the Court ruled that the Boy Scouts of America's First Amendment freedom of association rights permitted them to discriminate against gay scout officials. ${ }^{19}$ That same year, the Court made a very important ruling that any enhanced sentence to be imposed in a criminal case based on facts (such as hate crimes) had to be included in the criminal charge, and found beyond a reasonable doubt by a jury. ${ }^{20}$

A number of other important federal constitutional law cases, based on the Bill of Rights to the United States Constitution, have come from New Jersey. Those I have listed, however, give a flavor of the kinds of cases that have both won and lost at the national level, thereby providing building blocks for the body of federal constitutional law applicable everywhere in our country.

\section{The 1947 New Jersey Constitution and Modern Rights Guarantees}

The 1947 Constitutional Convention produced a thoroughly updated constitution for the state. ${ }^{21}$ Not only did it provide reformed and modernized judicial and executive branches, but it further updated the state constitution's Declaration of Rights. First, the wording of Article I, paragraph 1 was revised to change the reference to the inalienable rights of all "men," to all "persons.",22 This provision, which has been acknowledged by the New Jersey Supreme Court to be a state constitutional equal rights amendment for women, ${ }^{23}$ although not commonly recognized, put New Jersey among the earliest states to adopt such an amendment. ${ }^{24}$

Further, through the efforts of Oliver Randolph, the single African-American delegate to the 1947 Constitutional Convention, Article I, paragraph 5 was adopted, barring segregation in

\footnotetext{
${ }^{14}$ Everson v. Board of Education of Ewing Township, 330 U.S. 1 (1947).

${ }^{15}$ This led to the 1947 provision in the New Jersey Constitution specifically authorizing such public support of private and religious school transportation. N.J. Const. art. VIII, § IV, II 3.

${ }^{16}$ Greer v. Spock, 424 U.S. 828 (1976).

${ }^{17}$ Schad v. Borough of Mount Ephraim, 452 U.S. 61 (1981).

${ }^{18}$ New Jersey v. T.L.O., 468 U.S. 1214 (1984).

${ }^{19}$ Boy Scouts of America v. Dale, 530 U.S. 640 (2000).

${ }^{20}$ Apprendi v. New Jersey, 530 U.S. 466 (2000).

${ }^{21}$ Williams, supra note 2, at 13.

${ }^{22}$ Robert F. Williams, The New Jersey Equal Rights Amendment: A Documentary Sourcebook, 16 Women's Rts. L. Rep. 69 (1994).

${ }^{23}$ Peper v. Princeton University, 77 N.J. 55 (1978).

${ }^{24}$ Linda J. Wharton, State Equal Rights Amendments Revisited: Evaluating Their Effectiveness in Advancing Protection Against Sex Discrimination, 36 Rutgers L.J. 1201, 1202 (2005).
} 
public education and the militia. ${ }^{25}$ This clause, of course, predated by seven years the famous United States Supreme Court ruling in Brown v. Board of Education, outlawing segregated public education in the United States.

Finally, the convention proposed, and the voters accepted, the new Article I, paragraph 190, which guaranteed the right to collective bargaining for persons in private employment and the right to collective negotiation by public employees. This provision has been enforced by the courts in litigation by private employees even in the absence of implementing legislation. ${ }^{26}$

In much more recent years, these new state constitutional rights have been supplemented by another modern rights provision - a 1991 guarantee of victims' rights. ${ }^{27}$ This provision has also had an important influence on state constitutional law in New Jersey. ${ }^{28}$

\section{The Warren Court's Federalization of Constitutional Rights}

In the 1950s, beginning with Brown v. Board of Education, the United States Supreme Court, under the direction of Chief Justice Earl Warren, aggressively continued the selective incorporation of the rights contained in the federal Bill of Rights into the Due Process clause of the Fourteenth Amendment, thereby making them applicable to the states. This period of the "liberal" United States Supreme Court lasted well into the 1960s, and resulted in a "nationalization" or "federalization" of rights litigation. ${ }^{29}$ Almost all advocates of constitutional rights were mesmerized by, and relied upon, the expanding federal constitutional rights guaranteed by the Supreme Court. One scholar at the beginning of this era said "If our liberties are not protected in Des Moines the only hope is in Washington." 30

\section{The New Judicial Federalism}

In the 1968 presidential campaign, Republican candidate Richard Nixon based part of his platform on a promise to change the direction of the United States Supreme Court. Upon winning, he moved in this direction by appointing Chief Justice Warren Burger. This perceived conservative redirection of the Supreme Court led rights advocates to begin to look to their state constitutions as possible sources of protection beyond the national minimum (and likely reduced) standards guaranteed by the Supreme Court's interpretations of the federal constitution. ${ }^{31}$ State courts could, literally, disagree with the Supreme Court if their rulings provided rights that were

\footnotetext{
${ }^{25}$ Bernard K. Freamon, The Origins of the Anti-Segregation Clause in the New Jersey Constitution, 35 Rutgers L.J. 1267 (2004).

${ }^{26}$ Richard A. Goldberg \& Robert F. Williams, Farmworkers' Organizational and Collective Bargaining Rights in New Jersey: Implementing Self-Executing State Constitutional Rights, 18 Rutgers L.J. 729 (1987).

${ }^{27}$ N.J. Const. art. I, II 22.

${ }^{28}$ State v. Muhammad, 145 N.J. 23 (1996) (victims' rights amendment supports use of victim impact evidence at sentencing).

${ }^{29}$ Richard C. Cortner, The Supreme Court and the Second Bill of Rights: The Fourteenth Amendment and the Nationalization of Civil Liberties (Madison: University of Wisconsin Press, 1981).

${ }^{30}$ Monrad G. Paulsen, State Constitutions, State Courts and First Amendment Freedoms, 4 Vand. L. Rev. 620,642 (1951).

${ }^{31}$ Robert F. Williams, The Law of American State Constitutions 113-232 (2009).
} 
more protective than the national minimum standards or "floor." Justice William J. Brennan, Jr., formerly of the New Jersey Supreme Court, wrote an influential 1977 article in the Harvard Law Review $^{32}$ urging state courts to take their state constitutions seriously and not necessarily to follow the increasingly conservative direction of the United States Supreme Court. Justice Brennan (as well as Justice Thurgood Marshall) also expressed this view in dissenting opinions during that era. ${ }^{33}$

Importantly, New Jersey has been a leader in this reemergence of state constitutional law. ${ }^{34} \mathrm{~A}$ few of the many examples of the New Jersey Supreme Court's cases interpreting the state constitution to provide rights beyond the national minimum were the "Mount Laurel" exclusionary zoning decisions, ${ }^{35}$ adequate funding for education of poor public school students, ${ }^{36}$ death with dignity, ${ }^{37}$ abortion funding for poor women, ${ }^{38}$ search and seizure protections, ${ }^{39}$ free speech on privately-owned regional shopping mall premises, ${ }^{40}$ and rejection of required parental notification for minors' abortions. ${ }^{41}$

Decisions such as these in New Jersey, as well as similar rulings in virtually all of the other states, have truly reflected a "New Judicial Federalism." Well into this important jurisprudential development in which state courts are achieving parity with federal courts in rights protection, another scholar aptly noted: "For if our liberties are not protected in Washington, the only hope is in Des Moines." 42

Another important feature of the New Judicial Federalism was the recognition that state court decisions based on state constitutions could be overruled by the electorate, voting to adopt a proposed amendment to the constitution. ${ }^{43}$ In New Jersey, to date, there has only been one example of an amendment to the state constitution that was adopted to overturn a decision of the New Jersey Supreme Court recognizing rights above the federal, minimum standards. In 1988, the New Jersey Supreme Court had ruled in State v. Gerald ${ }^{44}$ that capital punishment could not be imposed on a defendant for felony murder unless there was evidence of intent to kill. In 1992, Article I, paragraph 12 of the New Jersey Constitution was amended to permit the imposition of capital punishment in such circumstances.

\footnotetext{
${ }^{32}$ William J. Brennan, Jr., State Constitutions and the Protections of Individual Rights, 90 Harv. L. Rev. 489 (1977).

${ }^{33}$ E.g., Michigan v. Mosley, 423 U.S. 96 (1976) (Brennan, J., dissenting).

${ }^{34}$ Williams, supra note 2, at 27-28.

${ }^{35}$ Southern Burlington Co. NAACP v. Mt. Laurel, 61 N.J. 151 (1975).

${ }^{36}$ Robinson v. Cahill, 62 N.J. 473 (1973); Abbott v. Burke, 575 A. 2d 359 (N.J. 1990).

${ }^{37}$ In re Quinlan, 70 N.J. 10 (1976).

${ }^{38}$ Right to Choose v. Byrne, 91 N.J. 287 (1982).

${ }^{39}$ State v. Hunt, 91 N.J. 338 (1982).

${ }^{40}$ N.J. Coalition Againt the War in the Middle East v. J.M.B. Realty Corp., 138 N.J. 326 (1994).

${ }^{41}$ Planned Parenthood of Central New Jersey v. Farmer, 165 N.J. 609 (2000).

${ }^{42}$ Michael A. Giudicessi, Independent State Grounds for Freedom of Speech and of the Press: Article I, Section 7 of the Iowa Constitution, 38 Drake L. Rev. 9, 29 (1988-89).

${ }^{43}$ Williams, supra note 30, at 29, 128.

44113 N.J. 40 (1988).
} 


\section{Adequate and Independent State Grounds}

State court decisions that are based on "adequate and independent" state law grounds cannot be reviewed by the United States Supreme Court. Quite simply, where such a state law basis for the decision exists there is no federal question of law to be reviewed. Under these circumstances, it is very important that such state court decisions clearly indicate that they are based on state-law grounds. Where this is not made clear, the Supreme Court has indicated that it has the ability to exercise its jurisdiction because federal and state law are intertwined in a way that makes it impossible to determine which was the basis for the decision. In 1983, the Supreme Court stated in Michigan v. Long:

Accordingly, when, as in this case, a state court decision fairly appears to rest primarily on federal law, or to be interwoven with the federal law, and when the adequacy and independence of any possible state law ground is not clear from the face of the opinion, we will accept as the most reasonable explanation that the state court decided the case the way it did because it believed that federal law required it to do so. If a state court chooses merely to rely on federal precedents as it would on the precedents of all other jurisdictions, then it need only make clear by a plain statement in its judgment or opinion that the federal cases are being used only for the purpose of guidance, and do not themselves compel the result that the court has reached. ${ }^{45}$

Based on this approach, the United States Supreme Court did accept and reverse the New Jersey Supreme Court's decision holding that school officials could not search a student's pocketbook without probable cause. ${ }^{46}$ Had the New Jersey Supreme Court indicated clearly that its decision was based on the state constitution, the Supreme Court would not have had jurisdiction over the case. The New Jersey Court, however, based its decision on the federal constitution, thereby opening the way for United States Supreme Court review and reversal.

On the other hand, the New Jersey Supreme Court's decision holding that the Boy Scouts had violated the New Jersey statue (not constitution) banning discrimination, and therefore seemingly based on a state law ground, was reviewable by the United States Supreme Court, and reversed, because the Boy Scouts themselves asserted that their federal constitutional rights to freedom of association had been violated. ${ }^{47}$

\section{Conclusion}

Based on this brief sketch of the evolution of both state and federal constitutional rights in New Jersey, together with the interesting and somewhat complex interrelationship between these two sources of constitutional protections, it is clear that our federal system results in a rather complicated and not particularly efficient landscape of rights guarantees for the people. However, a basic understanding of the evolution, and interdependence, of these sources of rights

\footnotetext{
45463 U.S. 1032, 1040 (1983).

${ }^{46}$ New Jersey v. T.L.O., 469 U.S. 325 (1985).

${ }^{47}$ Boy Scouts of America v. Dale, 530 U.S. 640 (2000).
} 
is not beyond the understanding of New Jersey citizens. Hopefully, this brief survey will add to that level of understanding. 